Portland State University

PDXScholar

Urban Studies and Planning Faculty

Nohad A. Toulan School of Urban Studies and

Publications and Presentations

Planning

$1-1-1993$

\title{
The Evolution of Federal Transit Policy
}

Sy Adler

Portland State University, d3sa@pdx.edu

Follow this and additional works at: https://pdxscholar.library.pdx.edu/usp_fac

Part of the Transportation Commons, and the Urban Studies and Planning Commons

Let us know how access to this document benefits you.

\section{Citation Details}

Adler, S. (1993). The Evolution of Federal Transit Policy. Journal Of Policy History, 5(1), 69-99.

This Article is brought to you for free and open access. It has been accepted for inclusion in Urban Studies and Planning Faculty Publications and Presentations by an authorized administrator of PDXScholar. Please contact us if we can make this document more accessible: pdxscholar@pdx.edu. 


\section{SY ADLER}

\section{The Evolution of Federal Transit Policy}

The first major piece of national transit legislation was enacted in 1964. By 1969 the Urban Mass Transportation Administration was the subject of a highly critical analysis by staff investigators for a Congressional Appropriations Committee, and in the early 1970s industry analysts sharply critiqued the rationality of urban transit policy in general. In 1981 the Comptroller General of the U.S. reported to Congress that the demand for transit subsidies was approaching crisis proportions. ${ }^{1}$ The U.S. government has come to play a greater role in the transit industry than do most European counterparts, provides more passenger subsidy per ride than any other country, and, though transit is everywhere subsidized, the U.S. federal government subsidizes a greater share of industry costs than most other national governments. ${ }^{2}$ This article examines the circumstances under which this particular industry-government relationship developed. As part of this industrial policy discussion, the article also looks at the culture of discourse that was present during the early intervention period and that has been characteristic of the transit policy community since that time. ${ }^{3}$

David Jones argues that the federal program failed to address the underlying causes of the widespread financial distress of the urban transit industry during the post-World War II period, a reflection of the fact that "yirtually no attention was given to the economics of transit operations."

$\mathrm{He}$ critiques federal government intervention on the grounds that "policy was being built for and around the racehorses, not the workhorses, of the transit industry," by which he means that policy focused on the suburb-tocentral city journey rather than on the intra-urban travel that was the bread and butter of city transit properties. Moreover, he claims that the 
federal bureaucracy charged with administering the transit program consistently deferred to local priorities and judgments. ${ }^{4}$

This article argues that transit policy was indeed captured-at the outset-by central business district activists in cities across the country seeking to enhance the locational advantages of their place in the face of increasingly intense competition from suburban business centers. The mayor of Atlanta, testifying to a congressional committee in 1961 on behalf of the American Municipal Association and the U.S. Conference of Mayors, precisely articulated the theme that Jones pinpoints as leading to policy failure: "The greatest dilemma is this. Mass transportation has failed to keep pace with the explosive growth of our suburban areas. . . . Our mass transportation facilities must be stretched out into these new suburban areas. . . . Most of the strangling congestion on our central city streets results from the fact that private operators find it unprofitable to expand their services into the less densely populated suburban areas. It is a vital public necessity that such service be provided. . . . If they are vital public necessities, yet unprofitable to operate privately, they must be subsidized." 5

The central city focus of the federal program reflected a strategic shift by transit advocates in congressional policy-making tactics, away from the commuter railroad problems of a few big metropolitan areas-and the jurisdiction of the congressional commerce committees that dealt with railroad transportation matters - toward a broader concern with urban transportation and related land-use issues. The constituency for intervention was broadened, and the issues were addressed by the more interventionist and city-oriented banking and currency committees. However, shortly after the legislative breakthrough in 1964, the transit program and its implementing bureaucracy were moved to the newly established $\mathrm{De}$ partment of Transportation, rather than being permanently lodged with the Department of Housing and Urban Development. Although it was not especially controversial at the time, the shift institutionalized a set of conflicts between Transportation's continuing efforts to rationalize the supply of transit facilities and deeply rooted congressional efforts to subsidize the competitive exertions of central city constituents.

These conflicts, whether expressed on the terrain of land use or of transport supply, were present in the original debates regarding the nature and purposes of transit policy, and reflected a growing executive branch concern with rationalizing the national government's myriad interventions in these spheres. ${ }^{6}$ This rationalizing concern, which characterized both Republican and Democratic administrations and grew in intensity as congresionally driven program subsidies escalated, is one of the key dimen- 
sions of transit industrial policy analyzed below. However, before turning to a discussion of the dynamics of intervention, the article first grounds the evolution of federal policy in the context of local responses to the decline of the mostly privately owned transit industry during the 1940s and 1950s.

\section{Responding to Industry Decline}

As the financial and service problems of urban transit worsened in the post-World War II period, industry leaders advocated several steps to restore profitable operations and to prevent government takeovers of private properties. However, as the limits of these responses became increasingly evident to central city business and to political and technical activists, and as competition between central business districts and growing outlying business centers intensified, downtown interests sought to create regionwide governmental transit agencies that would invest in the types of services and facilities that would enhance the accessibility and reception capacity of the core. Representatives of outlying business centers resisted these initiatives, which produced governmental transit agencies with limited capabilities. These local political constraints, combined with state legislative reluctance to subsidize urban projects, reinforced a turn by downtown activists to the federal government.

In order to reverse the declining fortunes of their industry, leaders exhorted transit firms to pursue several different strategies. These ideas were widely discussed in the industry press and successes were loudly trumpeted to encourage others to adopt the innovations. First and foremost, transit properties were advised to establish and maintain close working alliances with downtown merchants and property owners, major newspapers, and city political officials. The key to these alliances, according to their industry leadership, was an awareness of shared fate. The financial future of all the alliance partners was intimately related to the health of the downtown economy, and transit operators had to convince these others that a thriving central business district required a viable transit system. ${ }^{7}$

Solid working relationships would, in turn, facilitate the adoption of various street and parking management tactics that would expedite the flow of surface transit vehicles, thereby improving the efficiency of operations. These included the elimination of on-street parking in the downtown area during the day or at least during peak periods, the provision of fringe parking/shuttle bus service, controls on turning movements, and 
the radical notion of reserving traffic lanes on the main downtown routes exclusively for transit vehicles during rush hours. New Orleans and Chicago set up fringe lots in the late 1940s. Philadelphia banned on-street parking downtown during the 1952 Christmas shopping season, and later generalized the practice, following a suggestion made by the major transit company there, and in early 1956 Nashville set up the first traffic lane reserved exclusively for buses. ${ }^{8}$ Nashville's mayor Ben West, who was also a leading activist in the American Municipal Association during the 1950s, was hailed as a hero by the industry. The editors of Mass Transportation wrote in their report on the 1956 American Transit Association convention that "the best speech . . . was given by Mayor Ben West of Nashville, Tennessee. But we had the feeling that there was not complete realization by transit men that here, in the person of this energetic mayor and in the things that have been accomplished in Nashville, was every. thing transit seeks in the way of city operation." 9

Transit industry leaders also hoped that an alliance with downtown interests would lead to support for a set of long-sought changes in the regulatory environment within which privately owned firms operated, and in fare practices. These were aimed at reducing costs, boosting productivity, and enhancing revenues. The industry sought emancipation from what were perceived to be oppressive franchise taxes and gross revenue levies; rigid rate structures, which made it impossible to raise and lower fares in a timely manner; and severe constraints on operators' capacity to drop service on unprofitable lines. Houston, for example, lowered gross receipts taxes in 1952, and the press kept a scoreboard of reductions in various taxes and forms of regulatory relief granted by states and cities around the country. ${ }^{10}$

On the revenue side, industry leaders called for the introduction of distance-based or zonal fare structures and peak period pricing. Industry analysts noted that while off-peak riding was precipitously declining, peak-priced ridership was holding its own. Moreover, the postwar round of fare increases was driving away the short-haul passenger. In early 1956 Toledo instituted a downtown free fare zone as part of a zone fare system, and the St. Louis transit company reduced off-peak fares for downtown trips during shopping hours and also worked out a deal with downtown merchants to subsidize shopper travel. ${ }^{11}$

While the transit industry promoted these institutional, fare, and traffic management changes, their alliance partners representing downtown sought a variety of service innovations in return for their support. These had mostly to do, as the Atlanta mayor told the Congress in 1961, with extending service to rapidly developing suburban areas, and providing 
peak-period express service between these outlying areas and the central business district. These were the sorts of services that investors rooted in downtown sought to deploy in order to counter the competitive threat posed by suburban business centers and their acres of free parking. These were, however, the most costly services for the transit industry-already reeling from the financially devastating effects of the peaking problemto supply. ${ }^{12}$

The St. Louis Public Service Company, the major transit supplier in that city, was widely regarded as "The Showpiece of the Transit Industry," largely because of the property's heroic efforts to respond, on behalf of downtown, to the suburban challenge. The company instituted a number of peak-period express bus routes between outlying areas and the core and ran shopper expresses as well. It utilized park-and-ride lots in suburban areas and fielded the nation's largest fleet of air-conditioned buses. The company president lobbied incessantly for exclusive bus lanes on the downtown streets, as had been introduced in Nashville. Nashville Transit initiated De Luxe commuter service using a subscription bus approach in early 1955, as did the Cincinnati operation, and the Washington, D.C., transit firm proposed to offer subscription-type club express service. These were aimed at attracting the long-distance traveler. ${ }^{13}$

While there was some movement in the direction of these sorts of peak period, long-distance express services, privately owned firms generally resisted downtown pleas to increase significantly their offerings in this area. Pacific Electric Railway in Los Angeles, which had resumed a limited number of express runs in 1946 that had been suspended during the war explained that "express service during the peak hours of travel has stimulated such peak hour travel without any appreciable effect on the mid-day or off-peak travel. It is a well known fact that all peak-hour travel, while undoubtedly of material benefit to the community served and to the passengers using it, has had a detrimental effect upon the earnings of the Company." 14 While deteriorating financial circumstances sharply constrained the capacity of private firms to provide these sorts of services, the few city-owned transit systems in the country were checked by municipal boundaries. The San Francisco Municipal Railway, for example, inaugurated express services from outlying parts of the city and put buses on freeways as quickly as segments opened to traffic, but Muni could not penetrate the rapidly growing sections of the peninsula south of the city or extend into the eastern or northern parts of the bay region. ${ }^{15}$

As a result of the financial exhaustion of the private companies and the limits of city-based public alternatives, downtown activists initiated movements to create regionwide governmental transit agencies with the politi- 
cal and financial power to provide the kinds of facilities and services that were seen as crucial to the survival of the central business district. These same activists were also in the forefront of the drive to launch a massive freeway building program that would include urban extensions of the interstate system. Nashville mayor Ben West, hero of the transit industry, was also the chair of the American Municipal Association's Highways Committee. Testifying before the U.S. Senate Public Works Committee in 1955 about the national highway program, he articulated the cities' interest in metropolitan freeways and explained that a large-scale federal program was necessary because of rural domination of state legislatures. "We are going to be lost balls in the high weeds," he said, "because we cannot get enough money [from the states] to take care of that tremendous load of cost of acquisition of rights-of-way." 16

Downtown activists sought transport facilities that would radiate from the core into outlying areas. Combining freeway and transit facilities within the same right-of-way-a set of downtown/radial corridors-was their ideal configuration. Such transport facilities would enable people to make increasingly lengthy, metropolitan-scale trips quickly, and, together with parking lots, would supply the central business district with virtually unlimited reception capacity. The idea surfaced in Detroit in a 1920 s report by a group of five prominent businessmen calling for the construc. tion of a network of "superhighways" that would incorporate transit in the median strip. Rail transit in freeway medians was the objective of a Los Angeles Chamber of Commerce-led movement in that region in the late 1940s, and the first such facility in the U.S., a rail line in the median strip of the Congress Street Expressway in Chicago, opened in 1958. ${ }^{17}$ However, creating the governmental capacities that were necessary to finance such multimodal corridor projects, as well as separate transit facilities, was quite difficult politically.

California central business districts experienced the full force of suburban competition more intensely than elsewhere during the early postwar period. Efforts to create regional transit agencies in three California urban areas during the 1940s and 1950s reveal the political conflicts that attended these downtown responses. These conflicts would shortly charac terize other metropolitan areas as well. When the Los Angeles Chamber of Commerce launched its drive to create a rapid transit district that would place rail lines in several downtown/radial freeways-which the Chamber had played a leading role in winning-opposition surfaced in the large number of outlying business centers, within as well as without the city, to the new governmental entity. The basis of resistance was straightforward, reflecting the fundamental way in which the intense 
competition between business centers in the region to maintain and attract mobile capital investment structured the dynamics of transport politics: outlying business center representatives opposed subsidizing transport projects that would primarily benefit the Los Angeles central business district. ${ }^{18}$

The intense political conflict surrounding the downtown-oriented transit initiative produced, in 1951, the Los Angeles Metropolitan Transit Authority, which so clearly reflected the stalemate that prevailed in the region that it was thoroughly paralyzed for several years. In 1957 this regional government agency was finally enabled to buy out the private firms, but was too financially and politically constrained to implement much of the key elements of the downtown program. ${ }^{19}$

A downtown San Francisco-led rapid transit movement emerged shortly after its Los Angeles counterpart, which eventually succeeded in building the Bay Area Rapid Transit (BART) system. However, the same conflicts that characterized the Los Angeles experience surfaced in the Bay region, nearly derailing the project there as well. In the end, a much smaller system than transit activists originally conceived was built. During the early years of the transit movement in the Bay Area, the main line of conflict separated downtown activists in San Francisco and Oakland, with the Oakland leadership perceiving the San Francisco proposal as yet another attempt by its larger competitor to defend the historic pattern of regional domination and prevent downtown Oakland from playing the hegemonic officecommercial role in the rapidly growing East Bay portion of the region. The Bay Area Rapid Transit Commission was created in 1951, during the same legislative session as its Los Angeles analogue, and was equally as constrained. During the next few years, however, San Francisco and Oakland activists reached an accommodation-built around an underwater transbay tube-that promised to permit both downtowns jointly to penetrate rapidly growing suburban areas.

The Bay Area Rapid Transit District, created in 1957, reflected the San Francisco-Oakland settlement; however, the growth of several business centers on the peninsula south of San Francisco during the 1950s led to another rupture. Santa Clara County, which contains San Jose, refused to join the District, and San Mateo County, immediately south of the city, withdrew from the District a few years later. Financing for a much truncated three-county system, rather than the six-county network sought by San Francisco activists, was approved by the district electorate in 1962 , and limits on the district's bonding capacity further constrained system design and construction. ${ }^{20}$

Their efforts earned BART district activists a hero's welcome at congres- 
sional hearings, though. Senator Harrison Williams of New Jersey, the leading transit advocate in Congress, praised district representatives for doing "what in many areas has seemed almost impossible, to get the whole region, or most of the region, into a governing unit . . . each jealous, of course, of its own sovereignty, and have done an even harder job of giving them the power to raise the money." Following successful passage of the BART bond issue, Williams described it as "a governmental miracle that your people . . . voted to tax themselves for this magnificent proposed rapid transit line." 21

While the downtown Oakland leadership struggled with San Francisco over a regional rapid transit system, they faced their own local crisis. Oakland and several other smaller cities in the East Bay were served by Key System Transit Lines, one of the handful of big-city transit properties-St. Louis Public Service was another-controlled by National City Lines (NCL). NCL sought to maintain the profitability of its transit empire in large part through an effort to hold down wages, a strategy that produced a great deal of bitterness on the part of the unionized workers who toiled on its properties, particularly in the many smaller cities where NCL's wage discipline was especially strict. The Amalgamated Association of Street, Electric Railway, and Motor Coach Employees of America, which represented most NCL workers, also deeply resented the company's policy of refusing to submit contract disputes to arbitration. As NCL sought to hold the line on wages during the protracted period of industry decline, strikes on NCL properties increased in frequency, and the company was quite willing to take lengthy strikes in order to enforce its bargaining position.

The downtown Oakland leadership had to stand idly by while a Key System refusal to arbitrate provoked a seventeen-day strike in 1947 and a strike lasting two and a half months in 1953, severely affecting downtown business and retail sales. The latter strike was widely interpreted as an NCL effort to force a government buy-out of the property; the archconservative Oakland leadership reluctantly moved to comply. Blessed by Joseph Knowland, publisher of the Oakland Tribune and a leading activist in the right wing of the state and national Republican party, a coalition of downtown business, political and technical people sponsored the creation of the Alameda-Contra Costa Transit District, to take over Key System and provide transit service that would strengthen downtown Oakland's position in the East Bay. Key System had always staunchly resisted extending lines into growing areas and providing express services to the core. Knowland explained to his associates: "I am not an advocate of public ownership, as such. But we are here confronted with a condition, not a theory." 
The Oakland-centered regional transit government that Knowland and colleagues created was endowed with the broadest range of political and financial power of any such entity created before federal governmental intervention. The district was the only one in the country with an elected board of directors and unlimited power to tax property within its jurisdiction, and it was granted a larger proportional bonding capacity than was its larger Bay Area counterpart. However, even the powerful downtown Oakland coalition was constrained in its drive to encompass the entire East Bay region within its district's domain. Substantial portions of both Alameda and Contra Costa counties successfully resisted incorporation into the transit district, seeking instead to foster the growth aspirations of their own business centers. ${ }^{22}$

Similar competition-driven dynamics were in evidence elsewhere in the country as well. The Manhattan-centered plan of the New York-New Jersey Metropolitan Rapid Transit Commission drew the same kind of fire as in the Los Angeles and San Francisco-Oakland metropolitan areas. Business and political leaders in the larger New Jersey cities attacked the understanding that informed the commission's rail transit plan-that the metropolitan area constituted a single, integrated social and economic unit focused on the Manhattan central business district-and resisted the creation of a region-wide government agency that would impose the commission's plan on them. ${ }^{23}$ Efforts to create a Baltimore-centered metropoli$\tan$ transit authority were similarly stymied for several years during the 1950s, and the Chicago Transit Authority repeatedly failed to secure the capacity to implement major extension programs. ${ }^{24}$ In Washington, D.C., the House District of Columbia Committee decided that approval should be sought for only that portion of a proposed rail rapid transit system for the national capital region that was mainly within the District of Columbia due to serious suburban uncertainties regarding the location of the proposed rail lines. ${ }^{25}$

In mid-1961, just as the drive for federal intervention in transit was gathering steam, the trade journal Metropolitan Transportation surveyed the thirteen major regional transport agencies then functioning, including the New York City Transit Authority. All of these were constrained in various jurisdictional and/or financial ways from fully implementing the downtown corridor program, and in many other areas local conflicts had prevented the emergence of regional agencies at all. ${ }^{26}$ The transit districts and authorities, such as the Los Angeles Metropolitan Transit Authority, instituted as much long-distance, peak-period express service as they could. However, a combination of political conflict at the metropolitan level and state-level unwillingness to subsidize urban transport projects 
limited the capacities of the new agencies to act. City support for federal intervention, for both downtown/radial freeways and transit, increased in relation to these political obstacles.

\section{The Dynamics of Federal Intervention}

Downtown activists were supported in their natural legislative effort by some commuter railroads, the Railway Progress Institute representing rail equipment manufacturers, and the Institute for Rapid Transit, which included rail transit operators, equipment manufacturers, and transport planning and engineering consulting firms. They were championed by a growing number of congressional representatives who sought to advance the interests of their constituents. However, this alliance confronted a tentative executive branch. Tentativeness was a product of two contradictory sets of pressures bearing on top officials of both political parties and their executive appointees. On the one hand, national leaders of both parties sought to use metropolitan programs, including transit, to solidify relationships between national and local party organizations and to enhance the party's electoral appeal among target groups at the local level. The Democrats used urban programs aimed at traditional big-city strongholds in the Northeast, Midwest, and West during the Kennedy-Johnson years, and the Republicans adopted their own version aimed at suburban voters and the newer cities of the South, Southwest and Western areas during the Nixon period.

Executive branch officials, however, were also concerned about rationalizing the national government's growing involvement with metropolitan area problems. They worried about the budgetary impacts of the increasing amounts of subsidy, the extent to which the many programs were effectively coordinated, and the efficiency with which program objectives were addressed. Party-building and electoral concerns, along with congressional advocacy, have produced periodic transit program expansion. Rationalization efforts have sought continually to rein in subsidy commitments and discipline the allocation process according to efficiency objectives. Both tendencies are responses to the competition between places to maintain and attract mobile capital investment at the local level. Spatial competition engenders a continuing demand for transport projects that will create and maintain location advantages; executives continually search for ways to contain the fiscal crisis tendencies inherent in the growing number of project proposals.

The kinds of transit initiatives that downtown activists sought from the 
federal government to overcome their political and financial obstacles fell into three main categories: (1) institutional and financial access to interstate highway rights-of-way in order to realize fully the promise of the downtown/radial transport corridor; (2) grants to construct radial rapidtransit facilities-for rail and bus rapid transit, both inside freeways and separately - that would penetrate rapidly growing suburban areas; and (3) subsidies for equipment and labor to operate the new peak-period services. It took varying lengths of time to achieve these objectives. Institutional commitments at the national level were fairly easily secured. Subsidies for equipment preceded major support for construction and right-of-way acquisition, and operating subsidies were the most difficult to accomplish. By the mid-1970s, though, all the elements were in place.

City officials, local transit activists, and congressional advocates began calling for access to freeways during debates on the national highway program in the mid-1950s. The American Municipal Association resolved at its annual convention in 1957 that the federal Bureau of Public Roads should authorize plans and specifications for the inclusion of transit facilities as an eligible federal cost in the planning of the urban segments of the new interstates. The idea was also boosted by Harland Bartholomew, one of the nation's leading urban planners and the chairman of the National Capital Planning Commission. He said in 1957 that he would ask District of Columbia highway officials to reserve the median strips of two proposed highways for mass transit, and the proposed transportation plan released by the Bartholomew Commission in 1959 called for extensive bus and rail use of freeway rights-of-way and lanes as well. ${ }^{27}$

As part of the Kennedy administration's response to the downtown coalition's transit initiative, the president called for a report on the nation's mass-transit problems and needs to be jointly prepared by the Housing and Home Finance Agency and the Department of Commerce. This 1962 report concluded that "the Bureau of Public Roads will in the future (a) permit the reservation of highway lanes for the exclusive use of specific types of motor vehicles when comprehensive transportation plans indicate this to be desirable, and (b) encourage the development of rail transit and highway facilities in the same right-of-way whenever more effective transportation will result." ${ }^{28}$ In his transportation message to the Congress, presented shortly after receipt of the report, President Kennedy said that he had endorsed the recommendations, and during congressional testimony the federal highway administrator said that the Bureau of Public Roads was implementing what the President had approved, referring specifically to the charge given designers of the congressionally authorized Shirley Highway in the Washington, D.C., area to consider the inclusion 
of special bus lanes. The administrator also, however, called attention to the fact that funds to implement the transit portion of any joint use plan were not yet generally available. ${ }^{29}$

Walter McCarter, a former Chicago transit official and now president of the Institute for Rapid Transit recalled at congressional hearings in 1963 that he had worked closely with former Bureau of Public Roads chief Tom McDonald in the late 1940s on planning the jointly used Congress Street Expressway, and that McDonald had told him at the time that "If he had had the power . . . he would not have allowed an expressway to be built in any metropolitan area without a median strip wide enough for a private right-of-way [for mass] transportation. He did not have the power at that time. ${ }^{30}$ The mayor of Seattle, representing the American Municipal Association, also called on Congress to provide funds for advance right-of-way acquisition so that space might be reserved for transit. ${ }^{31}$

The first major piece of transit legislation, in 1964, made available federal grants for land acquisition, new equipment purchase, and facility construction. Money for land would enable local transit agencies to begin implementing their share of corridor development. Funds for equipment would permit locals to modernize and upgrade their vehicles and facilities. This element also amounted to a protectionist industrial adjustment policy aimed at stabilizing the rail equipment manufacturers who were prominent members of the transit coalition, and who stressed to Congress the dispersed character of their industry - plants in 468 cities in all but three continental states - and the likelihood of hiring back many of their workers who had been laid off in 1961. ${ }^{32}$ Construction grants would help to underwrite radial projects aimed at penetrating rapidly growing suburban areas. However, the amounts of money involved were modest. This reflected the still rather narrow basis of support for a program of transit intervention, which was concentrated among those urban areas where downtown already confronted suburban competition, and where existing private and public transit firms were clearly unable to help the central business district compete.

The next major expansion of the transit program was in 1970, as national Republicans deployed a metropolitan strategy aimed at newer cities in the South, Southwest, and West whose core areas were now beginning to feel the same sorts of competitive pressures as earlier had the older urban centers, and whose transit firms were now similarly financially exhausted. A lobbyist for the transit coalition noted that "now we have new horizon cities-younger and more expansive metropolitan areas in all sections of the country - wanting to build rapid rail systems to their suburbs.... In the next 20 years, all the new systems now on the 
drawing boards will be aimed at that 10 per cent of the SMSA . . . populations made up of commuter riders." ${ }^{33}$ Republicans and southerners were attracted to a program aimed at suburban constituencies. The amounts available for facility expansion and equipment were increased, and highway fund monies were made available for exclusive or preferential bus lanes and related uses. The 1973 highway act liberalized the use of funds for bus-transit-related purposes. ${ }^{34}$

Subsidizing the operation of expanded peak-period services was the one remaining item on the downtown coalition agenda. When he presented the Kennedy administration's transit proposal to Congress in 1963, Housing and Home Finance Administrator Robert Weaver was asked, "Do we envision, after making a Federal investment at the capital end of the structure . . . making future Federal contributions in the form of subsidies for the operation of these facilities?" Weaver responded, "We have never advocated such subsidies, and we have no intention of doing so." 35 Following passage of the 1964 legislation, though, Senator Harrison Williams, the leading congressional champion of transit, introduced a bill calling for operating subsidies, which failed. Once again, following the successful passage of the 1970 transit bill, the coalition sought operating subsidies. After a protracted campaign, in 1974 the Nixon administration decided to adopt, as part of a rationalization strategy discussed below, a revenuesharing approach within which local agencies could choose to allocate resources to capital or to operations and maintenance expenditures. ${ }^{36}$ The final piece of the downtown coalition program was now in place.

\section{Rationalizing Federal Government Intervention}

A key objective for national government executives has been to reduce the threat to the treasury of long-term subsidization. ${ }^{37}$ Several different ways of achieving this object have been tried. They have included national mandates that metropolitan areas created region-wide government agencies with the power to plan and to manage transport facilities. Research and development aimed at boosting productivity was sponsored as well. When mandates to plan proved inattentive to efficiency concerns, attention to these concerns was mandated. They waged ideological campaigns against expensive projects. Executive branch officials continually sought ways to minimize the role of legislative politics in decisionmaking, in the face of constant efforts by congressional advocates to champion the projects of their constituents. As the subsidy costs of the transit program grew, executives sought to restructure the industry 
through privatization and other marketlike strategies primarily aimed at strengthening management's capacity to reorganize the labor process and to reduce the wage bill. The focus of rationalization efforts shifted over time from increasing the efficiency and effectiveness of intervention in the urban development process to reining in the fiscal-crisis machine that had evolved.

Addressing downtown coalition transit proposals, Eisenhower administration executives called for comprehensive metropolitan land-use and transportation planning that would determine the nature and level of transit requirements and integrate transit and highway expenditures. These suggestions echoed concerns voiced by leading urban planners around the country following passage of the interstate highway program in 1956. In his 1960 congressional testimony on an early transit bill, Eisenhower's commissioner of urban renewal also stressed the absence of metropolitan governmental organizations that could finance and manage coordinated transport systems. These concerns, about governmental planning and management capacity at the metropolitan level, and about the nature and extent of subsidization, were present in the Kennedy administration as well. ${ }^{38}$

In 1961 the Kennedy administration supported increasing federal support for planning. Housing and Home Finance Administrator Robert Weaver wrote to President Kennedy, and testified to Congress shortly thereafter, that "unless cities prepare and adopt comprehensive community plans, including mass transportation plans as an integral part thereof, they may waste both their own and Federal funds and may aggravate rather than correct problems of urban congestion, haphazard development, and deterioration." Plans were intended to protect the value of investments that local and federal governments were about to undertake. ${ }^{39}$ Kennedy wrote to Congress that his proposed legislation would "stimulate urban areas to establish areawide agencies empowered to plan, develop, and operate transportation systems." 40 This was reinforced by the stipulation, contained in the joint report of the Secretary of Commerce and the Housing and Home Finance Administrator, that, after 1 July 1965 , only those highway projects that were consistent with areawide plans for a balanced transportation system would be approved. Kennedy also said that an approved comprehensive plan and "the existence of a suitable organization representing all, or substantially all, of the local governmental units in the metropolitan area" were absolute requisites to federal subsidy. ${ }^{41}$ Weaver highlighted the central importance of this last point to the national executive: "It [subsidy] has to go to some place where there is a central approach to the problem, or else 
we are going to dissipate our funds entirely and make chaos, rather than an improvement." 42

The emphasis on planning, governmental organization, and need assessment in the early 1960 s reflected the Democratic interest in party building and electoral support in central cities as well as a more general national executive interest in rationalizing the government's intervention in the urban development process. The institutional innovations were aimed at helping downtown activists achieve what they were unable to put in place at the metropolitan level due to spatial competition-induced political conflict and state legislative opposition. At the same time, executives placed the transit program in the context of increasing the efficiency of other federal programs aimed at central city support, including freeway building, urban and community renewal, and housing.

In his 1962 transportation message Kennedy discussed the essential need "to conserve and enhance values in existing urban areas," and the importance of promoting "economic efficiency and livability in areas of future development." He also noted that there was a need to intervene "to assure more effective use of Federal funds available for other urban development and renewal programs." 43 Lyle Fitch, president of the Institute of Public Administration, which did the research for the joint HHFACommerce study mentioned above, articulated this point clearly in his 1962 testimony to Congress: "In downtown areas the Federal Government is making very large investments for redevelopment and housing and so from the point of view of preserving the Federal investment already made and in prospect, it is highly important that we assist mass transportation." 44 Building local capacity to plan and evaluate was critical because, as Weaver told Congress, "This is a complex country, it is a heterogeneous country, and it is very difficult for us to get any staff in Washington that is going to be able to make this evaluation in every community. It is our feeling very strongly that this has to be a matter of local responsibility. ... And once you depart from this ... you are going to have a situation where the Federal Government is going to be dipping into a series of local situations, which is disastrous." 45

Echoing a comment made by Eisenhower's urban renewal chief, Weaver also told Congress that the government lacked both theory and data to discipline the nature and extent of federal subsidy: "I think . . . the biggest unexplored area-and one would assume there was a great deal of knowledge, but there really isn't-is the effect of more prompt, more satisfactory, more comfortable, more expeditious mass transit upon the rider. . . . [I]f you increase the service and if you make it . . . a little 
more reasonable, is the ridership going to increase? Because if this is true, then you have a whole set of economic possibilities. If it isn't true, then you are in an entirely different situation." 46 Weaver was here articulating an "economist" approach to policy analysis and intervention-a concern with the elasticity of demand for transit - to go along with the traditional government preference that in the case of infrastructure projects the userpay principle be applied to the greatest practical extent. Economist forms of reasoning would become increasingly important in the executive branch, especially after the institutional focus of the transit program shifted from its origins in land use and urban development to transport supply.

Interestingly, a little later in 1962 Senator Frank Lausche of Ohio, who was sponsoring a competing piece of transit legislation that did not include federal grants, showcased the only available example of precisely the sort of research that Weaver had described. Professor Leon Moses, research director at Northwestern University's Transportation Center, told a congressional committee about analyses that he was doing using Chicago travel data. The research question Moses discussed with Congress was: "What price structure would serve to divert automobile users to public transportation[?]" He noted that "no one else I know of has such figures or has been interested in doing such a study, and yet this is the essential criteria necessary for a bill to subsidize mass transit, if you are going to subsidize it, and have some notion of what the costs are going to be." He warned that "the experience in Chicago . . . proves it would be extremely difficult to carry out diversion, and extremely expensive. . . . [T] he cost of the program could exceed the cost of many other subsidy programs we are now involved in." 47 .

Congressional transit champion Harrison Williams mocked the caution counseled by the economist approach. Specifically attacking Moses, Williams told Lausche's committee, "There was one witness in particular who seemed agitated about the fact that we don't know with any scientific exactitude how much it would cost to divert $\mathrm{X}$ number of riders from their automobiles to their next best choice of public transportation. I just wonder where this country would be today if we had to await answers to similar questions about other problems facing the Nation. We would certainly have a lot of busy and well-paid researchers tucked away in our universities. . . . For the sad thing is that the question this witness thought was in urgent need of answering is completely irrelevant to the problem at hand." Williams cited evidence from the Boston area, and from Philadelphia, where improvements in service had been associated with increases in transit patronage to counter the claim that not enough 
was known about the dynamics of ridership. He also argued that the comprehensive planning requirements in his proposed legislation "which would determine the need, the value, the economic feasibility, and the utility of any particular transit service-is the key to the wise and prudent use of Federal funds." Williams agreed with Weaver that a metropolitanlevel planning capacity was essential because a national bureaucracy had no business telling local people how to solve their problems. ${ }^{48}$

The lack of interest in creating a substantial expert capacity at the national level, or in getting a handle on likely future levels of subsidy demand, reflected the congressional concern to advance the downtown agenda as far and as quickly as possible. Comprehensive planning was an arena within which to defend the interests of central business districts within metropolitan areas, and both Congress and the executive branch supported such an effort. However, suburban opposition to the recentralizing aims of such plans was increasing in intensity; it was a very weak hook upon which to hang a strategy aimed at rationalizing the urban development process.

The failure of authoritative metropolitan land-use planning agencies to emerge increased the significance attached by downtown activists to transport facilities. In the absence of plans that would maintain historic patterns of land use, they looked to the new metropolitan-scale projects to shape the dynamics of growth, so as to maintain the hegemony of the central business district in the face of suburban business center competition. Ironically, just as the federal government was committing its resources to using transport investments to shape the pattern of future metropolitan development, transportation planners engaged in plan preparation at the metropolitan level were concluding that it was essentially too late to accomplish this. There was already so much transport capacity in place that even the addition of a planned network of freeways and transit lines would at best marginally influence the pattern of metropoli$\tan$ land use. ${ }^{49}$

The politics of transport planning in Washington, D.C., provided early evidence of the obstacles confronting the planning strategy. A survey of mass-transportation needs was mandated by Congress. The steering committee overseeing the preparation of this survey decided not to publish a 1959 report prepared by the Institute of Public Administration - the only one of the support studies done for the mandated survey that was not published-because they disagreed with the institute's proposal to create a transportation organization embracing all modes of transport that would be closely related to an effective regional planning agency. The institute's report to the Secretary of Commerce and the Housing and Home Finance 
Administrator a few years later recommended that transit legislation contain a requirement for a regional planning process backed up by a regional decision-making authority. These requirements were left vague in the bills submitted to Congress. ${ }^{50}$

Congressional responsiveness to downtown concerns was the key element in the policy-making process. This prevented the establishment of a framework conducive to an economically rational policy of transit industry adjustment. The executive branch was able to resist one particular effort at obtaining subsidy, though: that of the Los Angeles Metropolitan Transit Authority to secure a federal guarantee of revenue bonds the Authority wished to sell to finance construction of a downtown/radial rail transit system. President Kennedy had referred in his transportation message to very specialized situations in which such a guarantee might be appropriate. Senator Clair Engle of California told his colleagues that he believed that "the language contained in the President's message-I worked very closely with the staff people who wrote that message-was placed in there because of the Los Angeles situation," and he sponsored a bill that would create the possibility of such a federal guarantee. However, largely based on Treasury Department opposition to a financing technique that might interfere with its debt-management and long-term bondfinancing requirements, Engle's measure failed to pass. ${ }^{51}$

Following the 1964 legislation, Congress added funds for research and training, as well as money for planning, engineering, and designing transport projects. Whether operating increasingly decimated private firms or continuing to operate the new governmentally owned transit systems, decades of retrenchment had produced a generation of transit managers who were inexperienced in image-building, marketing, technological innovation, and other forms of entrepreneurial activity. Moreover, the industry's poor financial prospects had held few attractions for a younger generation of managerial activists. Congress also added funds for technologically. oriented development. In the early 1970s, though, following several years of increasing demand for downtown/radial rail rapid transit systems, the executive faced, for the first time, applications for funds that would exceed available monies. ${ }^{52}$ The issue of prioritization posed a crucial test of the executive's capacity to conduct a rational industrial policy as well as to rationalize its own intervention.

Congress had closely questioned Robert Weaver about how the executive would establish priorities before the 1964 act. Weaver answered that top priority would be given to those projects that were an integral part of authoritative comprehensive plans. In addition, the government would support local efforts to deal with an emergency situation in which an area 
was threatened with the imminent loss of transit service. ${ }^{53}$ However, serious questions regarding intervention choices did not arise during the first few years following program start-up.

The question of allocation policy was complicated by the shift of the transit subsidy program to the Department of Transportation in 1968. The culture of Transportation disposed transit executives to the strict economist approach to financing infrastructure that characterized the department. Allocation policy was a highly controversial issue when Transportation was created in 1966 . The most controversy was generated by a section in the original proposal for the department that would have authorized the Secretary of Transportation to develop uniform standards and criteria for evaluating all federal investments in proposed transport projects. This clearly represented an effort to rationalize the transport investment process; all projects would be subjected to a total systemsoriented cost-benefit analysis. Representatives of the many modal interests were extremely concerned about this proposed section, and, with highway activists in the forefront, they persuaded Congress to restrict dramatically the scope of authority granted to the executive branch. While Congress determined to reserve for itself the lead role in project decision-making, however, the department continued to stress greater economic rationality in its varied interventions. ${ }^{54}$ Grant Davis noted that "the bills which have been submitted [to Congress] by the [Department of Transportation] reflect its philosophical orientation which favors utilization of the market mechanism and the elimination of excessive subsidy. Congress has not acted favorably to any of the recommendations by the department to increase user charges and thereby insure that transportation users pay their 'fair share.' Furthermore, when appearing before congressional committees, the organization is not held in high esteem." ${ }^{55}$

The departmental concern with rationalization was reinforced by toplevel appointments made by Nixon's Urban Mass Transportation Administrator in 1969. Most of these went to people with considerable managerial experience in the defense and aerospace industries rather than, as had been the case with the original federal transit program staff, to those with backgrounds in land transportation, urban planning, and transportation economics. A hardware orientation persisted within the agency, which was closely linked to efforts to enhance productivity within the transit industry. ${ }^{56}$ In an industry where wage costs account for the great bulk of operating expense, substituting capital for labor as a method of increasing productivity had a great deal of surface economic appeal. Moreover, given the extreme physical deterioration of the industry during its protracted period of decline, new technology had marketing appeal as well. The 
savings theoretically available from the substitution of multicar trains operated by one person for a multitude of buses each operated by a driver was a major justification for the rail transit demands that were surfacing.

The large number of downtown alliances seeking subsidy for expensive capital projects generated a great deal of budgetary anxiety. The White House had fears about the capacity of national transit executives to develop and implement a method for rationalizing access to subsidies when demand exceeded available grant funds. They were concerned that Congress would be irritated - and would intervene-when particular projects failed to secure funding commitments. In September 1973 the Office of Management and Budget instituted a moratorium on new projects involving railways and deleted all UMTA-requested money for rail projects in fiscal year 1975. An ideological campaign against rail projects was waged by the Department of Transportation and the UMTA administrator. UMTA also instituted an elaborate set of project planning requirements, including demands for cost-effectiveness analyses and the explicit inclusion of low-capital-cost approaches among the alternatives analyzed at the metropolitan level. 57

Altshuler and Curry sympathized with the procedural demands elaborated by federal bureaucrats in their efforts to "avoid becoming caught in the middle of local controversies, to limit demand for the scarce resources at their disposal, and to require both statutory compliance with comprehensive planning requirements and the highest standards of professional practice without appearing to impose their own values upon urban regions." Along with other transit industry activists and analysts, however, they felt that form was now driving substance out of transportation planning; the quality of governmental decision-making was suffering as a result of the emphasis on procedure. ${ }^{58}$

While UMTA struggled to sort out the mushrooming number of rail project proposals, the Nixon administration saw financial problems intensifying when the downtown coalition's demand for operating subsidies gathered strength in the early 1970s. Academic analysts and national transit executives forecast dire consequences if operations were subsidized. They predicted that subsidies would be used inefficiently to expand services, and that the fares charged for additional services would be far below the cost of their provision. In addition, they argued that transit workers would win substantial pay increases because the subsidies would undermine managerial resolve to impose wage discipline on organized labor. ${ }^{59}$ However, in the face of these plausible, articulate warnings, the administration was still forced to respond to the downtown demand to increase 
the most costly sort of service to provide-long-distance, peak-period routes connecting downtown with low-density suburban areas.

The executives chose to do so by embedding a local choice to use subsidy funds for either capital or operating expenses in a revenue-sharing format. The White House wanted to reduce the discretion available to executive branch officials because discretionary authority stimulated congressional efforts to influence its exercise. An approach that used formulas to allocate funds, combined with local choice about spending, was intended to minimize congressional intervention in the subsidy allocation process. If the executive could not rationalize its own allocation process, then setting an overall limit and shrinking the executive's decisionmaking sphere appeared to the administration as an attractive strategy to rationalize its own intervention. In the latter 1970s, though, Congress continued to increase the amount of subsidy available, as well as intervene in the rail project approval process over which federal executives still exercised discretion. ${ }^{60}$

The evolution of local and federal programs of financial support, adapted to the pressures of spatial competition at the metropolitan level, exacerbated the financial troubles of the transit industry. The critics of operating subsidies were right. The new services often carried relatively light loads. At the same time, transit labor was able to secure wage gains enabling them to keep pace with workers in other local government sectors during a very inflationary period. Moreover, transit worker resistance limited management's ability to reintroduce work practices that would soften the consequences of the continuing concentration of patronage in the peak hours, such as part-time labor and more split-shifts. Transit units also bitterly resisted efforts to contract out work to nonunion firms. The result of these dynamics was a dramatic decline in industry productivity. ${ }^{61}$

The crisis was political as well as financial. Outlying business center coalitions increasingly saw needs for locally-responsive transport going unmet while downtown coalition projects absorbed ever more subsidy. Many central business districts did so well strengthening their competitive position - with freeways as well as transit-that few financial resources remained to subsidize the transport-related growth aspirations of outlying areas beginning to experience suburban gridlock. Public-sector transit crisis has, in turn, generated a new round of efforts to restructure the industry and rationalize federal intervention, although the current situation is more complicated because of the presence of suburban business center activists in local, state, and federal political arenas. As a result of 
international competition, subsidy possibilities are now more constrained than during the 1960 s and 1970 s as well.

\section{The Culture of Policy Discourse in Urban Transit}

One of the more controversial reports prepared during the early legislative debates was Technology and Urban Transportation, by John R. Meyer, John F. Kain, and Martin Wohl. It was commissioned by the Panel on Civilian Technology, which was set up under the joint sponsorship of the President's Special Assistant for Science and Technology, the Chairman of the Council of Economic Advisers, and the Secretary of Commerce. The report was presented in June 1962 and released - though neither published nor endorsed - in October. ${ }^{62}$ Their charge was to identify areas for useful research in urban transportation. The authors construed their mandate broadly, discoursing on the present and likely future course of metropolitan development and the resulting significance for transport requirements. They also did cost comparisons between different modes of urban transit, reflected on the deep importance of social relations for a full understanding of transport supply and demand, and addressed the equity aspects of policy. The report exemplified the economist approach, stressing the need to evaluate the full costs of a proposed intervention through a comprehensive, systemwide analysis, to find ways of using existing resources more efficiently, rather than simply to expand capacity whenever bottlenecks appear, and to deploy a system of user charges to induce efficient behavior. The authors challenged many of the arguments being advanced on behalf of rail rapid transit projects. Within the industry, which was familiar with its contents, the report and the critical commentary it sparked generated a "bus versus rail" controversy, but the issues it raised went far beyond modal conflict.

Meyer, Kain, and Wohl called attention to the "underlying forces for decentralization [which] would be operative independent of any public policy influences since they are attributable to fundamental changes in technology, income levels and consumer tastes. ... [T] he availability and use of transit does not seem to be a sufficient or a necessary condition for creating density or downtown growth and, conversely, provides no major retardant or preventive to the development of new employment opportunities in the urban ring." ${ }^{33}$ Following an analysis of the comparative bus and rail transit costs of supplying a hypothetical downtown commuter trip, they argued that if the capacity of urban highways was efflciently utilized during peak hours, as a result of the use of priority access 
for transit vehicles and a set of charges for congested failures, foreseeable levels of travel demand could be accommodated.

In addition to their concern with efficient capacity utilization, Meyer, Kain, and Wohl also addressed the social and equity aspects of transit policy. They hypothesized that declines in off-peak shopping transit trips were related to the recent desegregation of buses in the South, and to a desire for racial segregation elsewhere as well. They forecasted a bimodal distribution of transit ridership; high-income executives, technicians and their secretaries, on the one hand, and unskilled labor used in service industries, on the other, mainly recruited from minority groups. They noted "the tendency of people with high incomes to substitute long distance commuting for direct solutions to the problems created by restrictions placed upon minority housing opportunities," suggesting that "it might be better to attack the housing segregation problem itself rather than attempting to perpetuate it by subsidizing additional transportation facilities for those whose travel demands are created by a search for segregation." In the absence of restrictions on minority housing choices, a major resettlement of higher-income people closer to the central business district - where many such people worked and would increasingly work in the future-might occur, which, they believed, would greatly reduce, or even eliminate, the commuting problem. ${ }^{64}$

Technology and Urban Transportation was bitterly attacked by the Institute for Rapid Transit as "replete with fallacious theories and assumptions, erroneous mathematical analyses, and prejudiced and undocumented conclusions." The institute, which was composed primarily of activist engineers working in transit operations, system design, and equipment manufacturing, was especially concerned about what it considered to be a distorted and biased cost comparison between bus and rail transits. However, the institute, which had positioned itself as a leading member of the downtown coalition seeking federal transit subsidy, also questioned Meyer, Kain, and Wohl's claim about the irreversible nature of the decentralizing forces: "The authors appear to be entirely blind to . . . downtown building booms [in New York and Chicago] and the national movement for strengthening and expanding central business districts. Surely the private interests, as well as local and federal governments in many instances, which are investing large sums of money in the downtown areas of the nation's great cities, do not accept the author's contention that the downtown area with its high concentration of population and activity is a thing of the past." 65

Senator Harrison Williams also voiced his concern about Technology and Urban Transportation. He worried that the authors were making a 
sweeping claim about what mode of transit was best for all metropolitan areas, when it was certainly "not the job of the federal government or others to tell a metropolitan area what modes of transportation it should have." Williams also thought that "it might be better to await the results from San Francisco before transit is consigned to the junk heap." The senator doubted that the authors, "who were asked to identify useful technological research areas, were fully qualified as observers of the social and economic urban scene" to comment on racial segregation. He questioned whether their suggestion to attack the housing problem rather than subsidizing transit "would also apply to future highway as well as transit expenditures, and whether the authors would go so far as to say that the problem of traffic congestion should be attacked by a program to get people to live within walking distance of their place of work," the implications being that they would be unwilling to extend the logic of their analysis in this manner, and in any case the latter notion was beyond the pale. ${ }^{66}$

Meyer, Kain, and Wohl's claim about the immutability of the forces producing decentralization - and that transit institutions and investments should efficiently serve these underlying forces-was the most serious challenge to planners, most of whom wanted to subordinate transport projects to land-use plans aimed at strengthening central business districts. In contrast to the economist discourse embodied in Technology and Urban Transportation, planners' discourse stressed a set of policy choices premised on the malleability of the future pattern of urban development. In a book based on the analytical work done for the joint CommerceHHFA study discussed earlier, Lyle Fitch and his Institute of Public Administration associates noted that "certain factors point to increased decentralization if past trends continue. But should they continue? Do we want density or dispersion? Do we prefer urban areas with a single center or with many functional nuclei? Should suburbs be integrated into the urban region or be largely self-contained? How should they be related to each other and to the central city? Do we want even development or urban land or clusters leaving sections of open space? These are questions which are unanswered in most developing urban areas and which vitally concern transportation planning as well as urban design." 67

Fitch and associates set out both sides of the debate between those who argued the "indispensability of the central city to our culture and economy" and the decentralists, who emphasized "the inevitability or desirability of dispersion of enterprises and population . . . throughout an urban region." They linked these positions on urban form to positions on transport supply, characterizing Meyer, Kain, and Wohl as highway proponents who ques. 
tioned "whether grade-separated mass transportation has an important role in the future urban complex," and who held that "planning should focus on the widely decentralized type of city, which is made possible and best served by the automobile." "68 At the national level, planning discourse focused on the subordination of transport projects to comprehensive land-use plans, leaving the resolution of the urban form debate to metropolitan planning processes. Fitch and associates justified intervention to subsidize transit on the basis that automotive transport in urban areas was subsidized, thereby distorting supply-and-demand choices, concluding that "if for historical reasons (good or bad), one mode of transportation is being subsidized by a certain amount per passenger trip, competing modes should be subsidized by at least roughly corresponding amounts per trip." Metropolitan planning aimed at reaching consensus on urban form goals would then take place without the distorting effects of unequal subsidy. ${ }^{69}$

Economist Leon Moses clearly expressed the focus of planning discourse at the local level as it contrasted with the economist emphasis on efficient capacity utilization. When he discussed with Congress the economist advice to increase the price of commuting by automobile as a way of inducing efficient capacity utilization, he cautioned that "city planners ... whose real concern is not traffic congestion and the inefficient use of highway capacity - viewed as a resource - but the economic future of our mature, central cities, should pause before accepting it," because instead of commuters shifting to transit in response to the price increase, "there is a strong possibility that the core area's traffic problem will be solved by reducing the number of people who work there." Working within the context of spatial competition, local planners and political leaders evaluated transport strategies from the perspective of their impacts on particular places; the place competition dynamic was absent from Meyer, Kain, and Wohl's analysis of policy conflict. Spatial competition would also prevent the emergence of consensus about metropolitan form goals that Fitch hoped planning would produce.

As was the case with Leon Moses's testimony regarding the elasticity of demand for transit, Technology and Urban Transportation played a minor role in legislative debates. The report was referred to by a few others, usually to support a critique of proposed legislation. The Investment Bankers Association of America cited the report to support their claim that "population growth in metropolitan areas has not been accompanied by a corresponding increased need for urban mass transit facilities," and that any transit subsidies should come from local governments rather than the national treasury. ${ }^{71}$ The American Road Builders' Association cited the paper to support its view that while a great deal was uncertain regard- 
ing commuter transportation problems, there was no question regarding the need for expressways; transit considerations, therefore, should not in any way compromise the integrity of the highway program. ${ }^{72}$ The Amalgamated Association of Street, Electric Railway, and Motor Coach Employees of America pointed to the report to illustrate its concern that the federal government would be subsidizing automation. Meyer, Kain, and Wohl had discussed the possibilities of automated buses operating in special guidance lanes as a way of reducing labor costs, and automating fare collection and vehicle loading and unloading. These sorts of technological changes, which, the union argued, would threaten the jobs and the living standards of transit workers, required provisions that would protect workers who were adversely affected. Analysts of the 1964 transit act have all noted the critically important role played by organized labor in the legislative success of the-bill. Reflecting the weight of organized labor in Democratic party politics at the national and local levels, transit unions were able to secure institutional guarantees aimed at ensuring that their members would not bear a disproportionate share of the burdens of industrial adjustment. Labor was thus positioned to seriously challenge management efforts to restructure the work process. ${ }^{73}$

Regarding the lessons to be learned from San Francisco, however, Meyer, Kain, and Wohl's critique of the BART plan anticipated later work critical of that system and of other rail transit ventures. ${ }^{74}$ They pointed out that a fixation on achieving very high average speeds on the line-haul portions of the Bay Area system had led to poor station spacing and location choices that would reduce access to potential patrons and lengthen door-to-door travel times, thereby depressing patronage. Their hypothesis of a link between racial segregation and rail transit investment would be supported as well. The transit lobby's coordinator during the 1970 legislative campaign said, "The Southerners in Congress are quite open about its being a white commuter program; Atlanta, for example, is downright blunt about it. . . . [T] here is no question the realization by politicians of who is going to benefit from the program-the middle and the upper middle class-isn't an enormous tactical aid for us in working with Congress, especially Republicans and Southerners." 75 The attributes of an economically viable transit system that they set out-differentiated services adapted to diverse consumer demands-became the objective of Reagan administration executives in the 1980s.

Planner desires to use transport investments to shape the pattern of metropolitan development and to strengthen the position of central business districts would continue to clash with economic admonitions that such efforts were both utopian and elitist, and that services instead should 
efficiently serve expressed patterns of demand. ${ }^{76}$ The planner's reliance on the growth-shaping potential of transport, though, reflected an effort to substitute transport projects for land-use plans. In the absence of plans that would constrain the use of projects to create location advantages for competing places, a great deal of growth-inducing transport capacity was put in place. The planning ideal, articulated by one of the charter members of the Urban Mass Transportation Administration, was to "plan our cities so that the demand for transportation is not allowed to expand without limit in the first place." 77 Instead, competition to retain and attract mobile capital rendered the planning ideal infeasible and overwhelmed economist efforts to rationalize the transit industry.

Senator Williams said to Institute for Rapid Transit president Walter McCarter, "You and I and others of like mind are going to have to preserve downtown commerce for the chamber of commerce." He phrased it this way because the U.S. Chamber of Commerce opposed federal intervention. "Of course," he continued, "in doing it, we will make transportation available to the suburbanite who needs the city, wants the city." 78 During the 1960s and early 1970s the concerns of large urban areas occupied a place near the top of the national agenda; downtown coalitions were able to overcome resistance to intervention. The way these coalitions shaped the transit industry adjustment policies that resulted generated fiscal and political crises. A rationalizing transit policy would have led to a concentration of shrinking industry energies on those services that could be most efficiently provided and the creation of new industrial means to serve those markets that required different approaches. This would have included breaking apart large, difficult-tomanage transit organizations and dramatically altering labor policies. The outcome, however, was very different. During the latter 1970s national executives attempted to discipline the subsidy allocation process through planning mandates. The Reagan administration, which had little interest in the big cities and in governmental intervention in domestic matters, tried more direct approaches to rationalize intervention. These included continuing efforts to eliminate, or at least to reduce, operating subsidies, the use of performance standards to allocate resources, and support for privatizing the very services that had been the heart of the downtown coalition program. These strategies at the national level accompanied suburban business center demands in many metropolitan areas to reorient the services provided by regional transit agencies to facilitate their own growth aspirations and to change institutional structures and finance mechanisms if necessary to do so. ${ }^{79}$ This much more complex, competi- 
tive metropolitan environment is the current context for efforts to once again restructure the transit industry; the dynamics that characterized the first phase, though, continue to influence policies of industrial adjustment.

Portland State University

\section{Notes}

1. Michael Danielson, Federal-Metropolitan Politics and the Commuter Crisis (New York, 1965); George Smerk, Urban Transportation: The Federal Role (Bloomington, 1965); Lewis Schneider, "Urban Mass Transportation: A Survey of the Decision-Making Process," in Raymond Bauer and Kenneth Gergen, eds., The Study of Policy Formation (Glencoe, Ill., 1968); Royce Hanson, "Congress Copes with Mass Transit," in Frederick Cleaveland, ed., Congress and Urban Problems (Washington, D.C., 1969); John Burby, "Mass Transit Agency Faces Planning, Staffing Problems in Shift from Rags to Riches," National Journal, 3 October 1970, 2152; David Miller, ed., Urban Transit Policy: New Perspectives (Lexing. ton, Mass., 1972); Comptroller General of the United States, Soaring Transit Subsidies Must be Controlled (Washington, D.C., 1981).

2. John Pucher, "Urban Public Transport Subsidies in Western Europe and North America," Transportation Quarterly 42 (July 1988).

3. David Vogel, "Government-Industry Relations in the United States: An Overview," in Stephen Wilks and Maurice Wright, eds., Comparative Government-Industry Relations (Oxford, 1987); R. Kent Weaver, The Politics of Industrial Change (Washington, D.C., 1985); Wyn Grant, Government and Industry: A Comparative Analysis of the U.S. Canada and the U.K. (Aldershot, England, 1989).

4. David Jones, Urban Transit Policy: An Economic and Political History (Englewood Cliffs, N.J., 1985), 120, 121.

5. William Hartsfield, in Urban Mass Transportation-1961, Committee on Banking and Currency, U.S. House of Representatives, 87th Cong., 1st sess., June 1961, 72.

6. Lawrence Brown, New Policies, New Politics: Government's Response to Government's Growth (Washington, D.C., 1983).

7. "Dear Mr. City Official," Mass Transportation 48 (August 1952); “A Bold Plan to Get People to Ride More," 51 (September 1955); Passenger Transport, 26 January 1953.

8. David Markstein and Myles Jarrow, "Fringe Parking-Shuttle Bus Plan Proves Successful in New Orleans and in Chicago," Mass Transportation 45 (March 1949); Passenger Transport, 5 December 1952 and 12 December 1952; Robert Mitchell, "A Diet for Vehicular Traffic or Starvation for Transit," Mass Transportation 48 (June 1952); Henry Barnes, "Traffic Engineering and Mass Transportation," Mass Transportation 48 (August 1952); "Nashville Reserves a Separate Lane for Buses," Mass Transportation 52 (February 1956). 26.

9. "The ATA Convention in St. Louis," Mass Transportation 52 (October 1956): 25-

10. "A Plea for Emancipation," Mass Transportation 46 (May 1950); Passenger Transport, 14 November 1952, 13 February 1959.

11. Peter Kocan, "Why Not Charge the Rush Hour Rider?" and David Canning, "Let Your Schedule Maker Set Your Rates," Mass Transportation 45 (December 1949); Peter Kocan, "Four Years of Fare Increases," Mass Transportation 46 (January 1950); "Bold Experiment in Toledo," Mass Transportation 52 (January 1956); W. C. Gilman and Company, St. Louis Metropolitan Area Transportation Study 1957-'70-'80 (New York, 1959). 
12. Jones, Urban Transit Policy.

13. "The Showpiece of the Transit Industry," Mass Transportation 52 (September 1956); "Nashville Transit Initiates De Luxe Commuter Service," and "Capital Transit Proposes Club Express Service," and John Jones, "Cincinnati Inaugurates Club Flyer Service," Mass Transportation 51 (February 1955).

14. Pacific Electric Railway Company, Rebuttal Testimony and Exhibits in Case 4843 (Sacramento, 1947), 20.

15. Seymour Adler, The Political Economy of Transit in the San Francisco Bay Area, 1945 1963 (Washington, D.C., 1980).

16. Ben West, in National Highway Program, Committee on Public Works, U.S. Senate, 84th Cong., 1st sess., 1955, 196-99.

17. Donald Davis, Conspicuous Production: Automobiles and Elites in Detroit, 1899-1933 (Philadelphia, 1988); Los Angeles Chamber of Commerce, Rapid Transit Action Group, Rail Rapid Transit-Now! (Los Angeles, 1948); Darrel Ward, "Chicago Denounces New Concept in Rapid Transit," Mass Transportation 58 (March 1962).

18. California Assembly, Preliminary Report of the Assembly Investigating Committee on Traffic Control, Assembly Journal, 23 March 1948, 448; Santa Monica Evening Outlook, 18 April 1949; Southwest Wave, 11 March 1948; Sy Adler, "The Transformation of the Pacific Electric Railway: Bradford Snell, Roger Rabbit, and the Politics of Transportation in Los Angeles," Urban Affairs Quarterly 27 (September 1991).

19. Sy Adler, "Why BART but no LART? The Political Economy of Rail Rapid Transit Planning in the Los Angeles and San Francisco Metropolitan Areas, 1945-1957," Planning Perspectives 2:2 (1987).

20. Adler, The Political Economy of Transit in the San Fransico Bay Area, 1945-1963.

21. Harrison Williams in Urban Mass Transportation-1962, Committee on Banking and Currency, U.S. Senate, 87th Cong., 2d sess., April 1962, 156; Urban Mass Transportation-1963, Committee on Banking and Currency, U.S. Senate, 88th Cong., 1st sess., $1963,86$.

22. "That St. Louis Arbitration," The Motorman, Conductor and Motor Coach Operator 55 (August 1947); D. McClurg, "30th Convention Notes," 57 (November 1949); "Proceedings of the Thirty-Third Convention," 63 (November 1955); Oakland Tribune, 12 September 1956; Adler, The Political Economy of Transit in the San Francisco Bay Area, 1945-1963.

23. Jameson Doig, Metropolitan Transportation Politics and the New York Region (New York, 1966).

24. "Baltimore Group to Offer Ownership Plan," Passenger Transport, 25 November 1955; "Baltimore Transit Bills Die in State Legislature," Passenger Transport, 5 April 1957; "City Presents Plan for Baltimore Area Transit Authority," Passenger Transport, 13 February 1959; "Study Commission Drafts New Bill to Create Transit Authority for Metro Baltimore Area," Passenger Transport, 8 January 1960; H. Polland, "What's Ahead in '64Chicago," Metropolitan Transportation and Planning, January 1964, 29.

25. William Murin, Mass Transit Policy Planning: An Incremental Approach (Lexington, Mass., 1971).

26. "Is a Super Agency the Answer?" Metropolitan Transportation 57 (August 1961).

27. "AMA adopts 1957 Policy Statement on Mass Transit," Passenger Transport, 11 January 1957; "Editorial," Mass Transportation 53 (December 1957); "Provision for Mass Transit Should Be Considered in Planning New Highways," Passenger Transport, 31 January 1958; "Urge Transit Strips in D.C. Highways," Passenger Transport, 15 November 1957; "Express Bus, Rapid Transit Network Proposed at D.C." Passenger Transport, 17 July 1959.

28. "Joint Report to the President by the Secretary of Commerce and the Housing and Home Finance Administration," in Urban Mass Transportation-1962, Committee on Banking and Currency, U.S. Senate, 87 th Cong., $2 \mathrm{~d}$ sess., 72.

29. "A Message from the President of the United States, 1962" in George Smerk, ed., Readings in Urban Transportation (Bloomington, 1968), 309; Rex Whitton in Urban Mass Transportation-1962, Committee on Banking and Currency, U.S. Senate, 129. 
30. Walter McCarter in Urban Mass Transportation-1963, Committee on Banking and Currency, U.S. Senate, 151.

31. Gordon Clinton in Urban Mass Transportation-1963, 190-91.

32. Holcombe Parkes in Urban Mass Transportation Act of 1962, Committee on Banking and Currency, U.S. House of Representatives, 87th Cong., 2d sess., 439-40.

33. William Lilley III, "Urban Interests Win Transit Bill With 'Letter-Perfect' Lobby. ing," National Journal, 19 September 1970.

34. George Smerk, The Federal Role in Urban Mass Transportation (Bloomington, 1991), 115-19.

35. Robert Weaver in Urban Mass Transportation Act of 1963, Committee on Banking and Currency, U.S. House of Representatives, 88 th Cong., 1st sess., 42.

36. Smerk, The Federal Role in Urban Mass Transportation, 123-29.

37. Dennis Quinn, Jr., Restructuring the Automobile Industry (New York, 1988).

38. E. Williams, Jr., and D. Bluestone, Rationale of Federal Transportation Policy (Washington, D.C., 1960), 52-54; David Walker in Metropolitan Mass Transportation, Committee on Banking and Currency, U.S. House of Representatives, 86th Cong., 2d sess., 1960, 7.

39. Robert Weaver in Urban Mass Transportation-1961, 4-5.

40. John F. Kennedy in Urban Mass Transportation-1961, 4.

41. Ibid., 4; "Joint Report to the President by the Secretary of Commerce and the Housing and Home Finance Administration," in Urban Mass Transportation-1962, Committee on Banking and Currency, U.S. Senate, 74.

42. Robert Weaver in Urban Mass Transportation-1961, 25.

43. "A Message from the President of the United States, 1962," 302-6.

44. Lyle Fitch in Urban Mass Transportation Act of 1962, 475.

45. Robert Weaver in Urban Mass Transportation Act of 1962, 90-91.

46. Robert Weaver in Urban Mass Transportation-1962, Committee on Banking and Currency, U.S. Senate, 116.

47. Leon Moses in Urban Mass Transportation-1962, Committee on Commerce, U.S. Senate, 37-50.

48. Harrison Williams in Urban Mass Transportation-1962, Committee on Commerce,

U.S. Senate, 135.

49. Melvin Webber, "Transportation Planning Models," Traffic Quarterly 15 (July 1961).

50. Murin, Mass Transit Policy Planning, 50.

51. Clair Engle in Urban Mass Transportation-1962, Committee on Banking and Currency, U.S. Senate, 123; Alan K. Browne, "Financing California Rapid Transit," Traffic Quarterly 17 (January 1963).

52. Smerk, The Federal Role in Urban Mass Transportation, 97-103, 131.

53. Robert Weaver, Urban Mass Transportation Act of 1963, 60.

54. Richard Barsness, "The Department of Transportation: Concept and Structure," Western Political Quarterly 23 (September 1970); Herman Mertins, Jr., National Transportation Policy in Transition (Lexington, Mass., 1972).

55. Grant Miller Davis, The Department of Transportation (Lexington, Mass., 1970), 190.

56. Edmond Kanwit, "The Urban Mass Transportation Administration: Its Problems and Promise," in David Miller, ed., Urban Transportation Policy: New Perspectives (Lexing. ton, Mass., 1972).

57. Smerk, The Federal Role in Urban Mass Transportation, 131-32.

58. Alan Altshuler and Robert Curry, "The Changing Environment of Urban Develop" ment Policy-Shared Power or Impotence?" Urban Law Annual 10:3 (1975).

59. William Lilley III, "Transit Lobby Sights Victory in Fight for Massive Subsidy Program," National Journal, 4 March 1972. 
60. Smerk, The Federal Role in Urban Mass Transportation, 132; U.S. Urban Mass Transportation Administration, Feasibility of Federal Assistance for Urban Mass Transportation Operating Costs (Washington, D.C., 1971); "Mass Transit: The Expensive Dream," Business Week, 27 August 1984.

61. Don Pickrell, "Federal Operating Assistance for Urban Mass Transit: Assessing a Decade of Experience," in Transit Pricing and Performance, Transportation Research Record 1078 (Washington, D.C., 1986).

62. John R. Meyer, John F. Kain, and Martin Wohl, Technology and Urban Transportation (Washington, D.C., 1962); Joseph Ingraham, "Car-Bus Transit for Cities Urged," New York Times, 30 October 1962.

63. Meyer, Kain, and Wohl, Technology and Urban Transportation, 21.

64. Ibid., 42-43, 46-49, 58, 91, 94, 97-98, 112-14.

65. "An Evaluation of a Report Entitled 'Technology and Urban Transportation,' " Institute for Rapid Transit Newsletter 4 (August 1963): 5-9.

66. Harrison Williams, Jr., "Who's Right in Rail-Bus Row?" Metropolitan Transportation 59 (January 1963): 25.

67. Lyle Fitch and Associates, Urban Transportation and Public Policy (San Francisco, 1964), 20.

68. Ibid., 20-21.

69. Ibid., 156.

70. Leon Moses in Urban Mass Transportation-1962, Committee on Commerce, U.S. Senate, 48,50 .

71. Investment Bankers Association of America in Urban Mass Transportation-1963, $398-403$.

72. American Road Builders' Association in Urban Mass Transportation Act of 1963, $555-57$.

73. Bernard Cushman in Urban Mass Transportation-1963, 328-29; See the sources cited in note 1.

74. Meyer, Kain, and Wohl, Technology and Urban Transportation, 106; Melvin Webber, The BART Experiment: What Have We Learned? (Berkeley, 1976).

75. William Lilley III, 'Urban Interests Win Transit Bill With 'Letter-Perfect' Lobbying," National Journal, 19 September 1970, 2026.

76. Peter Hall and Carmen Hass-Klau, Can Rail Save the City? (London, 1985); Martin Wachs, "U.S. Transit Subsidy Policy: In Need of Reform," Science, 30 June 1989; New Urban Rail Transit: How Can Its Development and Growth-Shaping Potential Be Realized? Committee on Banking, Finance, and Urban Affairs, U.S. House of Representatives, 96th Cong., 1st sess., 1980; Andrew Hamer, Selling Rail Rapid Transit (Lexington, Mass., 1976).

77. Kanwit, "The Urban Mass Transportation Administration," 86-87.

78. Harrison Williams in Urban Mass Transportation-1963, 150.

79. Sy Adler, Understanding the Dynamics of Innovation in Urban Transit (Washington, D.C., 1986). 